\title{
ASUHAN KEBIDANAN PADA BALITA DENGAN GIZI KURANG DI PUSKESMAS GARUDA KOTA PEKANBARU TAHUN 2019
}

\author{
Liva Maita ${ }^{1)}$ Devi Nuraini ${ }^{2)}$ \\ STIKes Hang Tuah Pekanbaru
}

\begin{abstract}
ABSTRAK
Gizi kurang adalah keadaan kurang zat gizi tingkat sedang yang disebabkan oleh rendahnya asupan energi dan protein dalam waktu cukup lama yang ditandai dengan berat badan menurut umur (BB/U) yang terdapat pada Kartu Menuju Sehat (KMS) menunjukan angka <-3SD sampai dengan <-2SD tabel baku WHO-NCHS atau garis kurva berada di warna kuning. Adapun salah satu faktor penyebab terjadinya gizi kurang pada anak adalah penyakit infeksi, makanan yang tidak seimbang dan pola asuh anak. Laporan kasus ini bertujuan untuk melaksanakan asuhan kebidanan pada balita dengan gizi kurang secara menyeluruh dan berkesinambungan melalui metode pendekatan pendokumentasian SOAP. Pengambilan kasus dilaksanakan dengan mendatangi Puskesmas Garuda Pekanbaru dan kemudian dilakukan kunjungan rumah pasien.

Kesimpulan dari asuhan kebidanan An. R dengan gizi kurang, setelah dilakukan asuhan kebidanan selama 3 kali kunjungan kepada pasien maka hasil yang di dapat pada kajian terakhir yaitu gizi kurang dengan kategori status kurva KMS menurut BB/U berada di warna kuning. Disarakan untuk Puskesmas Garuda agar mendatangi rumah balita dengan gizi kurang untuk langsung memberikan biskuit khusus balita dengan gizi kurang.

Kata kunci : : Asuhan Kebidanan, Balita, Gizi Kurang
\end{abstract}




\section{LATAR BELAKANG}

Gizi kurang adalah keadaan kurang zat gizi tingkat sedang yang disebabkan oleh rendahnya asupan energi dan protein dalam waktu cukup lama yang ditandai dengan berat badan menurut umur $(\mathrm{BB} / \mathrm{U})$ yang terdapat pada Kartu Menuju Sehat (KMS) menunjukan angka <- 3SD sampai dengan <-2SD tabel baku WHO-NCHS (Kemenkes, 2011).

Masalah gizi kurang masih tersebar luas di negara-negara berkembang termasuk di Indonesia, masalah yang timbul akibat asupan gizi yang kurang diantaranya Kurang Energi Protein (KEP), Kekurangan Vitamin A (KVA), Gangguan Akibat Kekurangan Yodium (GAKY), dan Anemia. Gizi juga sangat berpengaruh terhadap perkembangan otak dan perilaku, kemampuan bekerja dan produktivitas serta daya tahan terhadap penyakit infeksi (Irianti, 2019).

Ada beberapa hal yang menjadi penyebab gangguan gizi, baik secara langsung maupun secara tidak langsung. Penyebab langsung gangguan gizi pada anak khususnya pada balita adalah tidak sesuainya jumlah gizi yang diperoleh dari makanan dengan kebutuhan tubuhnya. Penyebab tidak langsung gangguan gizi yaitu adanya pantangan atau kebiasaan yang merugikan terhadap bahan makanan tertentu (pola asuh), sosial ekonomi dan penyakit infeksi (Anik Sholika, 2017).

Setiap anak mengalami tahap pertumbuhan dan perkembangan dalam masa hidupnya. Pertumbuhan meliputi perubahan tinggi badan, berat badan, gigi, struktur tulang dan karakteristik seksual. Untuk mengetahui tumbuh kembang anak terutama pertumbuhan fisiknya digunakan parameter antropometri. Berat badan dan panjang badan merupakan salah satu ukuran antropometri yang terpenting karena dipakai untuk memeriksa kesehatan anak pada semua kelompok umur biasa dapat di lihat pada Kartu Menuju Sehat (KMS) (Kementerian Kesehatan RI, 2014).

Berdasarkan data UNICEF menunjukkan pada tahun 2012 diperkirakan 25\% atau 162 juta anakanak diseluruh dunia mengalami malnutrisi, sedangkan di Indonesia terdapat $36 \%$ balita yang mengalami malnutrisi. Gizi kurang merupakan salah satu masalah gizi utama pada balita di Indonesia. Prevalensi gizi kurang dan gizi buruk mulai meningkat pada usia 6-11 bulan dan mencapai puncaknya pada usia 12-23 bulan dan 24-35 bulan (Irianti, 2019).

Secara nasional tahun 2007 prevalensi gizi buruk adalah $5,4 \%$ dan gizi 
kurang 10,9\%. Pada tahun 2010 prevalensi gizi buruk sebesar $4,9 \%$ dan gizi kurang 11,9\%. Sedangkan pada tahun 2013 prevalensi gizi buruk dan gizi kurang mengalami peningkatan sebesar 5,7\% dan 13,9\%. Untuk mencapai sasaran MDG tahun 2015 yaitu 15,5\% maka prevalensi gizi buruk dan gizi kurang secara nasional harus turun sebesar $4,1 \%$ dalam periode tahun 2013 - 2015 (Fauziah, Lilis, Rahman, Nurdin, \& Hermiyanti., 2017).

Status gizi buruk dan gizi kurang di Provinsi Riau pada tahun 2018 yaitu $18,5 \%$. Rata-rata angka status gizi buruk dan kurang gizi berdasarkan Riskesdas tahun 2018 yaitu $17,7 \%$ sedangkan target RPJMN yaitu $17,0 \%$. (Riskesdas, 2018).

Berdasarkan data sasaran program kesehatan yang di dapatkan dari Dinas Kesehatan Kota Pekanbaru tahun 2018 terdapat 21 Puskesmas yang ada di seluruh Kota Pekanbaru. Data tersebut menyatakan bahwa terdapat 5 puskesmas tertinggi dengan kejadian gizi kurang pada balita, mulai dari urutan yang pertama yaitu Puskesmas Sidomulyo jumlah gizi kurang pada balita yaitu 69 orang, urutan yang ke dua adalah Puskesmas Garuda dengan jumlah gizi kurang yaitu 57 orang, urutan yang ke tiga yaitu Puskesmas Rejosari dengan jumlah gizi kurang yaitu 27 orang, urutan ke empat yaitu Puskesmas Senapelan dengan jumlah gizi kurang 25 orang, dan yang terakhir yaitu Puskesmas Harapan raya dengan jumlah gizi kurang yaitu 13 orang.

Selama penulis melakukan Praktik Klinik Kebidanan (PKK) di Puskesmas Garuda, penulis mendapatkan ada kejadian gizi kurang pada balita di salah satu Posyandu wilayah kerja Puskesmas Garuda. Dari uraian tersebut, penulis tertarik melakukan asuhan kebidanan pada balita dengan gizi kurang di Puskesmas Garuda Kota Pekanbaru.

\section{METODOLOGI KASUS}

Metode laporan ini adalah studi kasus dengan latar belakang asuhan kebidanan pada balita dengan gizi kurang. Pengambilan kasus dilakukan di Garuda pada tanggal 27 Juni 2019 sampai 10 Juli 2019.

Intrumen yang digunakan berupa format pendokumentasian asuhan kebidanan pada balita, buku KMS yang dimiliki pasien, perlengkapan pemeriksaan balita (timbangan berat badan, alat ukur tinggi badan bayi, pita meteran, dan thermometer), media untuk konseling yang digunakan berupa brosur/ lefleat. 


\section{KAJIAN KASUS}

\section{Kajian I}

Kunjungan pertama dilakukan pada tanggal 27 Juni 2019, pukul 06.20 WIB di rumah paisen.

\section{a. Kajian Data Subjektif}

Anak usia 25 bulan, jenis kelamin: laki-laki, anak ke-2, mengalami demam sudah 4 hari, sudah berobat ke klinik terdekat. Tidak minum susu formula karena anak tidak mau. Terlihat rewel karena tidak enak badan. Pada bulan Juni ibu tidak datang ke posyandu untuk melakukan penimbangan $\mathrm{BB}$. BB bulan April 9,8 kg, BB bulan Mei 9,8 kg. Imunisasi anak lengkap yang di lakukan di Rumah Sakit Zainab. Tidak memiliki riwayat peyakit keluarga/ menurun. Nafsu makan kurang, waktu tidur siang rata- rata setiap hari hanya 30 menit. Suami seorang pedagang dan Ibu tidak bekerja, menjaga anak dirumah. Keadaan ekonomi keluarga menengah. Hubungan sosial dengan lingkungan sekitar baik.

\section{a. Kajian data Objektif}

Keadaan umum anak baik dan terlihat rewel, Berat Badan $9 \mathrm{~kg}$, Tinggi Badan $80 \mathrm{~cm}$, Suhu $37,7^{\circ} \mathrm{C}$, Nadi $116 \mathrm{x} /$ menit, Pernafasan $35 \mathrm{x} /$ menit, Lingkar Lengan $13 \mathrm{~cm}$, Lingkar Kepala 45 cm.

\section{b. Assasment}

An. R, usia 25 bulan dengan gizi kurang disertai demam 4 hari.

\section{c. Plan}

Informasi dan edukasi

1. Memberitahu hasil pemeriksaan, BB $9 \mathrm{~kg}$, TB $80 \mathrm{~cm}$, Suhu $37,7^{\circ} \mathrm{C}$, Pernafasan $35 x /$, LL $13 \mathrm{~cm}$, LK $45 \mathrm{~cm}$.

2. Menganjurkan ibu untuk memberikan makan $3 \mathrm{x}$ sehari dan memberikan cemilan seperti roti, bubur kacang hijau, buah-buahan, dan yang lainya yang memiliki gizi baik.

3. Lanjutkan obat demam dan dan disertai mengompres dengan air hangat di bagian kening, 
leher, ketiak, dan perut. Jika

sudah sembuh, hentikan

pemberian obat penurun panas.

4. Memberitahu ibu akan ada kungjungan rumah pada tanggal 03 Juli 2019.

\section{Kajian II}

Kunjungan kedua dilakukan pada tanggal 03 Juli 2019, pukul 09.30 WIB di rumah paisen.

\section{a. Kajian Data Subjektif}

Anak sudah dapat beraktifitas seperti biasa. Anak sedang mengkonsumsi sarapan dengan bubur ayam yang dimakan sendiri tanpa bantuan orang tua. Makanan kesukaan anak yaitu nasi dengan lauk pauk seperti tahu, tempe, telur, dan sayuran yang diolah dengan berbagai jenis masakan. Makanan yang tidak disukai anak yaitu ikan. BB anak pada tanggal 27 Juni 2019 yaitu 9 kg.

\section{b. Kajian data Objektif}

Keadaan umum anak baik, Berat Badan 9,2 kg, kenaikan BB yaitu 0,2 kg. Tinggi Badan 80 cm, Suhu $37,1^{\circ} \mathrm{C}$, Nadi $112 \mathrm{x} /$ menit, Pernafasan $30 \mathrm{x} /$ menit, Lingkar Lengan $13 \mathrm{~cm}$, Lingkar Kepala $45 \mathrm{~cm}$.

\section{c. Assasment}

An. R, usia 25 bulan dengan gizi kurang .

\section{d. Plan}

Informasi dan Edukasi

1. Memberitahu hasil pemeriksaan, $\mathrm{BB}$ 9,2 $\mathrm{kg}$ dan kenaikan BB dari minggu lalu yaitu $0,2 \mathrm{~kg}$. BB saat ini masih tidak sesuai dengan umur anak karena status kurva pada KMS menurut $\mathrm{BB} / \mathrm{U}$ berada di warna kuning.

2. Memberitahu ibu cara memvariasikan makanan agar anak tidak bosan dengan makanan yang dimakan dengan cara membentuk berbagai jenis karakter atau membuat semenarik mungkin.

3. Memberitahu makanan selingan yang mudah di dapat dan bergizi seperti puding buah-buahan ataupun jus buah, roti, bubur 
kacang hijau, bubur sumsum dan lain-lain.

4. Memberitahu ibu bahwa akan dilakukan kunjungan rumah pada tanggal 10 Juli 2019.

\section{Kajian III}

Kunjungan kedua dilakukan pada tanggal 10 Juli 2019, pukul 09.30 WIB di rumah paisen.

\section{a. Pengkajian Data Subejktif}

Anak sudah dibawa ke Posyandu pada tanggal 08 Juli 2019 dan di dapatkan hasil BB yaitu 9,5 kg. Petugas kesehatan menganjurkan ibu untuk membawa anak ke Puskesmas agar mendapatkan biskuit khusus untuk penambahan berat badan tetapi ibu tidak bersedia karena alasan yang tidak diketahui. Pada tanggal 03 Juli 2019 di dilakukan penimbangan $\mathrm{BB}$ yaitu 9,2 $\mathrm{kg}$. Saat ini anak sudah mengkonsumsi sarapan dengan roti marrie dan teh hangat. Pemberian makan utama tetap 3 kali sehari, dengan lauk pauk seperti tahu, tempe, telur, dan sayuran yang diolah dengan berbagai jenis masakan. Sudah diusahakan untuk dibuat semenarik mungkin.

\section{a. Pengkajian Data Objektif} Keadaan umum anak baik, Berat Badan 9,5 kg, kenaikan Berat Badan yaitu 0,3 kg. Tinggi Badan $80 \mathrm{~cm}$, Suhu $37,1{ }^{\circ} \mathrm{C}$, Nadi 110 x/i, Pernafasan 30 $\mathrm{x} / \mathrm{i}$, Lingkar Lengan $13 \mathrm{~cm}$, Lingkar Kepala 45 cm.

\section{c. Assasment}

An. $\mathrm{R}$ usia 25 bulan dengan gizi kurang.

\section{d. Plan}

Informasi dan edukasi

1.Memberitahu hasil pemeriksaan, bahwa saat ini BB anak yaitu 9,5 kg, kenaikan BB anak dari tanggal 03 Juli 2019 yaitu 0,3 $\mathrm{kg}$, tetapi tetap belum sesuai dengan umur. Karena, menurut $\mathrm{BB} / \mathrm{U}$ pada $\mathrm{KMS}$ untuk anak laki-laki dengan usia 25 bulan BB normal antara $10 \mathrm{~kg}$ sampai $15,5 \mathrm{~kg}$. Dengan BB yang baik, maka anak akan sehat dan juga tidak mudah untuk terserang penyakit. 
2. Menganjurkan ibu untuk tetap memberikan makanan seimbang dan membentuk makanan supaya menjadi lebih menarik.

3. Menganjurkan ibu agar anak banyak istirahat yaitu tidur siang 2 jam dan tidur malam 9 jam.

4. Menganjurkan ibu untuk tetap rutin mengikuti posyandu agar mengetahui tumbuh kembang anak.

5. Menyarankan ibu pergi ke Puskesmas untuk mendapatkan biskuit khusus anak untuk membantu penambahan berat badan. Karena hal tersebut adalah salah satu program dari pemerintah.

\section{PEMBAHASAN}

Pada data subjektif ditemukan bahwa anak rewel karena sedang mengalami demam sudah 4 hari dan nafsu makan anak berkurang. Menurut teori (Alimul, 2010) anak yang menderita penyakit akan mengalami penurunan berat badan dan juga penurunan nafsu makan.
Kemudian anak terbiasa makan sendiri tanpa pantauan orang tua dalam waktu lebih kurang 1 jam makanan habis. Faktor yang menyebabkan anak lama menghabiskan makanan adalah sambil menonton TV. Menurut teori (Sudjatmoko, 2011) salah satu faktor yang menyebabkan anak lama untuk mengabiskan makanan adalah kurangnya perhatian orang tua terhadap anak/ pola asuh.

Pada data objektif di dapatkan keadaan umum anak baik, BB bulan Juni: $9 \mathrm{~kg}, \mathrm{BB}$ bulan Juli: 9,5 kg terjadi kenaikan BB 0,5 kg. Dinilai dari BB/U, saat ini BB anak termasuk pada kategori "T" (tidak naik). Menurut teori (Kementerian Kesehatan Republik Indonesia, 2015) anak laki-laki usia 25 bulan dan memiliki BB 9,5 kg termasuk dalam kategori gizi kurang, karena status kurva KMS terletak di warna kuning. Saat dilakukan pengukuran lingkar lengan di dapatkan hasil yaitu $13 \mathrm{~cm}$. Menurut (Septikasari, 2018), lingkar lengan normal anak balita yaitu $14 \mathrm{~cm}-$ $15,2 \mathrm{~cm}$.

Memberitahu ibu bahwa berat badan anak saat ini tetap belum sesuai dengan umur, menurut teori (Kementerian Kesehatan Republik Indonesia, 2015) anak di nyatakan gizi 
kurang jika berat badan tidak naik 2 kali

berturut-turut atau pun garis kurva KMS berada di warna kuning.

Mengingatkan ibu kembali untuk memberikan makan $3 \times$ sehari dan juga membentuk makanan semenarik mungkin agar anak tidak bosan. Karena menurut teori (Septikasari, 2018)

Pemberian makan 3 x shari dengan memperhatikan prinsip keanekaragaman atau variasi makanan akan memenuhi kebutuhan gizi seseorang. Kemudian tetap mengajurkan ibu untuk mengajak anak istirahat selama 2 jam untuk tidur siang dan 9 jam untuk tidur malam. Menganjurkan ibu untuk tetap mengikuti posyandu secara rutin agar mengetahui tumbuh kembang anak, menurut teori (Febry, 2012) fungsi Kartu Menuju Sehat (KMS) untuk mencatat berat badan, memantau pertumbuhan anak setiap bulan dan sebagai media penyuluhan gizi dan kesehatan.

\section{KESIMPULAN}

Setelah mengumpulkan data secara keseluruhan dapat dibuat kesimpulan yaitu An. R usia 25 bulan dengan gizi kurang, berat badan berada di status kurva berwarna kuning.

\section{SARAN}

a. Bagi Puskesmas Garuda

\section{Pekanbaru}

Diharapkan kepada Puskesmas Garuda untuk lebih memperhatikan balita dengan gizi kurang dengan cara langsung mendatangi rumah balita untuk memberikan makanan tambahan yaitu biskuit khusus balita dengan gizi kurang.

b. Bagi STIKes Hang Tuah Pekanbaru

Diharapkan pada pihak STIKes untuk lebih banyak menyediakan buku tentang gizi kurang supaya menjadi pedoman untuk studi kasus selanjutnya.

\section{c. Bagi Penulis}

Diharapkan pada penulis selanjutnya mendapatkan waktu yang sesuai untuk melakukan studi kasus yang dapat memantau kenaikan berat badan hingga dalam batas normal.

\section{DAFTAR PUSTAKA}

Alimul, A. (2010). Pengantar Ilmu kesehatan anak untuk pendidikan kebidanan. Salemba Medika. Jakarta . 
Anik Sholika, dkk. (2017). Faktor -

Faktor yang Berhubungan dengan

Status Gizi Balita di Pedesaan dan

Perkotaan. Jurnal Kesehatan

Masyarakat, 2(1), 9-18.

Fauziah, Lilis, Rahman, Nurdin, \&

Hermiyanti. (2017). Faktor Risiko

Kejadian Gizi Kurang Pada Balita

Usia 24-59 Bulan Di Kelurahan

Taipa Kota Palu. Ilmiah

Kedokteran, 4, 29.

Irianti, B. (2019). Faktor- Faktor Yang

Menyebabkan Status Gizi Kurang

Pada Balita Di Wilayah Kerja

Puskesmas Sail Pekanbaru Tahun

2016. Midwifery Journal: Jurnal

Kebidanan UM. Mataram, 3(2), 95.

https://doi.org/10.31764/mj.v3i2.478
Kemenkes, R. (2011). Buku sk antropometri.

https://doi.org/10.1055/s-0029-

$\underline{1219204}$

Kementerian Kesehatan RI. (2014).

Peraturan Menteri Kesehatan

Republik Indonesia Nomor 66 Tahun 2014 Tentang Pemantauan Pertumbuhan, Perkembangan, Dan Gangguan Tumbuh Kembang, 1365 .

Riskesdas. (2018). Hasil Utama Riskesdas Tentang Prevalensi Diabetes Mellitus di Indonesia 2018. https://doi.org/1 Desember 2013

Sudjatmoko. (2011). Masalah makan pada anak, 10(1), 36-41. 